The final version of this paper appeared as:

Rudolf, Winfried. "Wulfstan at Work: Retrieving the Autographs of London, British Library,

Additional 38651, fols. 57r-58v." In Anglo-Saxon Micro-Texts, edited by Ursula Lenker and Lucia

Kornexl, 267-306. Anglia Book Series 67. Berlin: De Gruyter, 2019.

https://doi.org/10.1515/9783110630961-013

The publication was produced in the context of ECHOE - Electronic Corpus of Anonymous Homilies in Old English. This project has received funding from the European Research Council (ERC) under the European Union's Horizon 2020 research and innovation programme (Grant No. 772744).

Winfried Rudolf*

\title{
Wulfstan at Work: Recovering the Autographs of London, British Library, Additional 38651, fols. 57r-58v
}

\begin{abstract}
This article retrieves the hitherto mostly illegible drafts of four short texts by Wulfstan, archbishop of York (d. 1023), in London, British Library, Additional 38651, fols. $57 \mathrm{r}-58 \mathrm{v}$. The autograph manuscript, which can be dated to the first years of the second millennium, provides not only an authentic basis for the description of Wulfstan's distinctive style, it also offers unique insights into his compositional method as homilist, his relation to Ælfric of Eynsham at the beginning of his career as archiepiscopal legislator, and the nature of the manuscripts from which a mobile prelate of his day was preaching. The short texts, described, edited, and translated here for the first time, witness Wulfstan's efforts of reconciling the moral and theological idealism of Ælfric with the realpolitik of his own day.
\end{abstract}

*Corresponding author: Winfried Rudolf, Georg-August-Universität Göttingen

E-Mail: winfried.rudolf@phil.uni-goettingen.de

\section{$1 \quad$ Wulfstan's Original Handwriting}


Ever since Arthur Napier's ground-breaking edition of 1883, scholarship on Wulfstan, Archbishop of York (d. 1023), has been fascinated with the power of his preaching and his role as legislator and state-builder. ${ }^{1}$ Scholars have since been eager to establish a reliable canon of his works, based on the definition of his idiosyncratic style, which seems to combine a specific two-stress rhythm with various kinds of binomials, repetitive lexis, compositional variation, and a range of signature phrases. ${ }^{2}$ Until the 1960 s, methods to establish the Wulfstan canon had primarily centred on his vocabulary, mostly excluding palaeographical evidence which could have facilitated the exercise. It was not until Neil Ker's 1971 article on the handwriting of the archbishop, published in the festschrift for Dorothy Whitelock, that Anglo-Saxonists were given a first comprehensive overview of Wulfstan's skills as an "experienced interpolator" (Ker 1971: 315) as well as corrector of drafts and copies made for him. Ker also established solid criteria for the identification of his hand.

Today, no fewer than ten manuscripts are thought to contain specimen of Wulfstan's original handwriting, both in Latin and Old English. ${ }^{3}$ Most of these samples concern additions of titles, single words, and phrases as well as corrections, often found in the form of marginalia or interlineations. Consecutive autograph Wulfstan, however, especially in Old English, is rare.

\footnotetext{
${ }^{1}$ The first to notice Wulfstan's authorial identity was Humfrey Wanley (1705: 141-143). For Wulfstan's biography see especially Whitelock (1942), Bethurum (1957: 54-87 and 1966), Gatch (1977: 18-23) and Wormald
} (2004). For his role as legislator see especially Whitelock (1948) and Wormald (1999: 330-366).

${ }^{2}$ On Wulfstan's canon see, for example, the studies of Napier (1882 and 1883), Kinard (1897), Becher (1910), Jost (1950: 110-117 and 183-270), Bethurum (1957: 24-49), Whitelock (1976), Wilcox (1992), Wormald (2000: 208-213), Orchard (2002). Wulfstan's style has been discussed on various linguistic levels and in specific depth, for example, by Mohrbutter (1885), Daniels (1904), Dunkhase (1906), McIntosh (1948), Menner (1948), Jost (1950: 155-168), Bethurum (1957: 87-89), Kubouchi (1999: 37-46), Orchard (1992 and 2004), Dance (2004: 2961), Pons-Sanz (2007) and Chapman (2017: 41-62).

${ }^{3}$ The manuscripts in question are Cambridge, Corpus Christi College, 190, pt 1 (s. xi ${ }^{1}$ ), p. iii-xii and 1-294; Copenhagen, Kongelige Bibliotek, Gamle Kongelige Samling, $15954^{\circ}$ (s. xi $\left.{ }^{1}\right)$, fols. 48r, 65v-66v and 81r; London, British Library, Additional 38651 (s. xi in), fols. 57-58; London, British Library, Cotton Claudius A.iii (s. x/xi ${ }^{1}$ ), fols. 31-86 and 106-50; London, British Library, Cotton Nero A.i (Worcester or York, s. xi in), fols. 70-177; London, British Library, Cotton Tiberius A.xiii (Worcester, s. $\mathrm{xi}^{1}-\mathrm{xi}^{\mathrm{ex}}$ ), fols. 1-118; London, British Library, Cotton Vespasian A.xiv (Worcester or York, s. xi ${ }^{1}$ ), fols. 114-179; London, British Library, Harley 55 (s. $\mathrm{xi}^{1}$ ), fols. 1-4; Oxford, Bodleian Library, Hatton 20 (S.C. 4113) (890×897); Oxford, Bodleian Library, Hatton 402 (S.C. 4117) (Brittany, s. ix²; France, s. x); Rouen, Bibliothèque municipale, 1382 (U109), fols. 173r-198r; and York, Minster Library, Additional 1 (s. $\mathrm{xi}^{1}-\mathrm{s}$. xi ${ }^{2}$ ). See Ker (1971: 319-331); for samples of Wulfstan's hand in facsimile Loyn (1971: appendix). Additional justification of Ker's attributions is provided by Wormald (1999: 191-228). See also Orchard (2012) for Wulfstan's library established on the basis of manuscripts containing his autograph hand. 
Apart from twelve lines (followed by four in Latin) on fol. 66v of Copenhagen, Kongelige Bibliotek, Gamle Kongelige Samling, $15954^{\circ}$, there are only about fifty Old English words in London, British Library, Cotton Nero A.i (fol. 120r) that complete a paragraph on worldly kings in his Institutes of Polity. ${ }^{4}$

One of the autograph manuscripts listed by Ker is London, British Library, Additional 38651, fols. 57r-58v, two leaves whose inner sides are covered with "hardly legible jottings, written apparently by Wulfstan in a smaller script than he used elsewhere" and containing "much more [text] than can be read" (Ker 1971: 321). ${ }^{5}$ The text that is now illegible under white light was damaged, apparently through treatment of the leaves with a reagent such as hepar sulphuris or hydrocloric acid that may have been carried out at some point in the nineteenth century. ${ }^{6}$ This has caused the inner pages $(57 \mathrm{v}$ and $58 \mathrm{r})$ to be largely covered by a blue stain. ${ }^{7}$ Using the most recent technologies of multispectral photography and digital image manipulation it is, however, possible to recover much of Wulfstan's writing on these pages (see Figures 2-5, pp. $\square$ below), of which $\operatorname{Ker}(1957: 162)$ could print only about thirty words. ${ }^{8}$

I will present here for the first time a description, transcription, partial reconstruction, and translation of the four short texts on these pages. One may call them 'micro-texts' because a) they are short and written in a small hand and b) they do not seem to have been rubricated and hence appear to be sketched and note-like in character, not least because of their unusual layout and missing ruling. It is for these reasons that this fragmentary material offers a very rare, if not unique, and utterly fascinating impression of Wulfstan at work in his various roles as writer, correspondent of Ælfric of Eynsham (d. c. 1010), legislator, and preaching

\footnotetext{
${ }^{4}$ Jost (1959: 41), Ker (1971: 320 and 323), and Loyn (1971: appendix). A digital image of the folio in Nero A.i is available under $<$ http://www.bl.uk/manuscripts/Viewer.aspx?ref=cotton_ms_nero_a_i_f120r>.

${ }^{5}$ See also Gneuss and Lapidge (2014: no. 294). Facsimiles of both folios can be found in Loyn (1971: appendix, pl. VIII and IX).

${ }^{6}$ The leaves were added to Additional 38651 in c. 1912, then already damaged. See the description in the Catalogue of the Additions to the Manuscripts in the British Museum (in the years MDCCCCX-MDCCCCXV), vol. 19 (1925), p. 179: “G. (2) Two flyleaves, much stained, containing writing in Anglo-Saxon, a quotation from Jeremiah iv.10 in Latin, etc. Vellum. xi cent. (?).”

${ }^{7}$ On common reagents used on parchment manuscripts, including their chemical formulas, see Fuchs (2003). A detailed study of the application of reagents in the early nineteenth century, with reference to C. Maier's treatment of the Vercelli Book, is Bock (2015).

${ }^{8}$ I am especially indebted to the British Library's imaging scientist Christina Duffy for undertaking multispectral photography of these folios and for providing some excellently merged digital images. For possibilities of recovering Anglo-Saxon erasures with the help of image viewing software see Stokes (2011).
} 
(arch)bishop. Wulfstan's autographs in Additional 38651 represent hitherto unrecorded Old English, a gift befitting the recent jubilee of Professor Helmut Gneuss, who has moved mountains to define the surviving manuscript corpus of Old English for future generations.

\section{London, British Library, Additional 38651, fols. 57r-58v}

Folios 57r-58v of London, British Library, Additional 38651 have been described by Ker (1971: 321) as endleaves or covers "taken from the medieval binding of some rebound manuscript in the Cotton, Harley, or Royal collections", but matching them with a known carrier manuscript remains difficult. ${ }^{9}$ Ker's entry in his Catalogue (1957: no. 130) needs some slight correction, since the leaves differ somewhat in size (fol. 57 has $232 \times 145 \mathrm{~mm}$, whereas fol. 58 measures $223 \times 150 \mathrm{~mm})$, no doubt due to later trimming. ${ }^{10}$ The outer hair sides $(57 \mathrm{r}$ and $58 \mathrm{v}$ ) show the wear of friction and exposure, but 57r has three (instead of Ker's two) large crosses of c. $25 \times 15 \mathrm{~mm}$ - one each at the top, centre, and bottom - while $58 \mathrm{v}$ shows only one cross placed at its centre. ${ }^{11}$ This specific feature, as much as Wulfstan's small hand in all items and the indelicate parchment, no doubt connects the two leaves and may suggest that they belonged to a portable bifolium or formed the outer leaves of a booklet rather than part of a larger codex. ${ }^{12}$ There is no sign of any ruling on either of the main written pages $(57 \mathrm{v}$ and $58 \mathrm{r}$ )

\footnotetext{
${ }^{9}$ The leaves are found in section $\mathrm{G}$ of the manuscript, titled "Miscellaneous fragments from bindings". Ker (1971: 321), typically cautious, does not completely rule out Nero A.i. as the potential original carrier, but this manuscript seems too small in format.

${ }^{10}$ The bottom trimming by c. 5-7 $\mathrm{mm}$ of fol. 58 has caused some damage of what appears to be the last line of text. By comparison the text block on fol. 57 seems complete.

${ }^{11}$ The crosses may signify an episcopal document and invite the threefold blessing with the sign of the cross accompanied by the In nomine patris formula by the reader/performer before opening the booklet. The sign of the cross also signals authority, for example at the beginning of King Alfred's Preface to the Old English translation of Gregory the Great's Regula Pastoralis in Oxford, Bodleian Library, Hatton 20, fol. 1r as well as at the beginnings of numerous Anglo-Saxon royal or episcopal charters.

${ }^{12}$ I disagree with Ker on the issue of the folios being non-conjugate (1957: 162). Single, probably portable, quires containing single homilies can be found for example in Oxford, Bodleian Library, Hatton 115 and Oxford, Bodleian Library, Auct. F.4.32 ('St Dunstan's Classbook'; Robinson 1994: 25-35). Additional 38651 fulfils a number of criteria of a booklet, as listed by Robinson (1994: 27), such as the soiled and rubbed outer pages, the fact that the final item ends on the final page with the endleaf being almost blank. The mostly non-identical wormhole pattern (Ker 1957: 162) may, in my opinion, result from the folios' later reuse as pastedowns, or
} 
on which traces of text can be found in an area of c. $205 \times 125 \mathrm{~mm}$. Fol. $57 \mathrm{r}$ shows a single readable insular $f$ half way between the top and middle cross on the left; fol. $58 \mathrm{v}$ has very faint traces of two to three lines of writing at the top.

All four texts were written in Wulfstan's hand, although his hand is notably smaller than elsewhere, and they show the typical palaeographical features that have been thoroughly described by Ker (1971: 316-319) and need no full repetition here, including the inconsistent graphic segregation between Latin and Old English, especially $g$ and $r$ (Ker 1957: 162 and 1971: 316-317), the generally forward-sloping ductus, long ascenders, or the curving upstroke of $d$. One may add to Ker's observations that Wulfstan almost exclusively prefers long $s$ (probably to avoid confusion with his descending, almost Caroline $r$ ), initial $b$, crossed $b$ for $p æ t$ ' that', and $m$ with superscript stroke to abbreviate $m e n$ 'people' when writing Old English. ${ }^{13}$

\section{Language}

The most recent reliable overview of Wulfstan's typical orthography, lexis, and syntax has been provided by Richard Dance (2004) and the newly retrieved texts in Additional 38651 largely correspond to the features outlined by him, which again require no full repetition here. Wulfstan's language generally reflects a Late West Saxon dialect, as for example in the long /a:/ of æghwar 'everywhere' (fol. 57v/22; Brunner 1965: § 321), the long /y:/ (for the $i$-mutation of Proto-Germanic */au/) in gyman 'to take care of, to observe' (fol. 57v/34; Campbell 1959: §

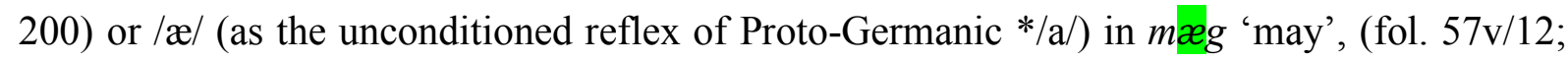
Campbell 1959: $\S \S 131-133,164-169,288-290) .{ }^{14}$ In accordance with Dance's observations, notable orthographic markers in the recovered texts are Wulfstan's standard $<y>$-spelling in $h y$ 'they' (fol. 57v/14), swyðe 'very' (fol. 57v/14) and pysse 'this' (fol. 57/12) (Dance 2004: 34), to which could be added his prefered $<\mathrm{hs}>$ spelling in ahsige 'ask' (fol. 58r/24) and rihsað 'reigns' (fol. 57v/12) (Brunner 1965: § 209). The present plural indicative of preterite-present verbs' inflexion with -an, rather than the orthodox -on, can be found in magan (fol. 58r/36; Dance 2004: 35). Particularly striking may be the spelling hefenum 'in the heavens' (fol. 58r/27;

flyleaves. There is, in my opinion, one common wormhole, ca. $90 \mathrm{~mm}$ from the top and ca. $50 \mathrm{~mm}$ from the left margin of the rectos.

${ }^{13}$ For the meanings of Old English words throughout this paper see the DOE (letters $A-I$ ) and Bosworth-Toller.

All translations in this paper, unless indicated otherwise, are my own.

${ }^{14}$ See also Dance (2004: 32). 
Dance 2004: 35-36). Dance's search for occasional East Anglian or even South Eastern features in Wulfstan's language is not based on autographs and Additional 38651 shows, for example, the contradictory non-Anglian breaking in healde 'keep' (fol. 58r/9; Campbell 1959: § 143). However, the Anglianism fracod 'insult, infamy, wickedness' (fol. 57v/23; Menner 1948: 3; Dance 2004: 46) occurs, as well as the potentially Anglian forms pæne (Akk. of pe 'the', fol. 58r/30; Brunner § 79) and mænnisc 'human’ (fol. 58r/21; Brunner § 79). We can also identify the lexical use of wis 'wise' (fol. 57v/25) and wær 'aware, prudent' (fol. 57v/25), apparently favoured by Wulfstan throughout his work (Dance 2004: 47).

A description of Wulfstan's style, solely based on lexical preference for specifically nouns and verbs, as so often carried out in previous scholarship (e.g. Jost 1950: 155-157; Whitelock 1976: 17-18; Dance 2004: 45), is, however, problematic and not without its dangers: not only creative minds such as Wulfstan's, who take delight in variation, but also human beings in general, know more and can use more than one expression for a concept during their lifetimes, as is not least evident from an abundance of alternative glosses in medieval manuscripts. Moreover, very few of the nouns and verbs so often assigned to Wulfstan can be identified exclusively with him when judged in relation to the complete corpus of surviving Old English. ${ }^{15}$ Rather, it is phrase and frequency that turn particular words into the 'wolf's howling'. And so we find in Additional 38651 the typical rate of intensifiers (e.g. ealles to swyðe 'all too much' [fol. 57v/16]; geornlice 'eagerly' [fol. 58r/6]; swyðe pearle 'very severely' [fol. 57v/21]; Bethurum 1957: 90), the - often alliterating or rhyming - binomials (e.g. magan 7 moton 'can and must' [fol. 58r/36], oft 7 gelome 'often and frequently' [fol. 57v/15], stalu 7 cwalu 'theft and murder' [fol. 57v/21], wær 7 wis 'aware and wise' [fol. 57v/25]) as well as distinctive collocations (e.g. æghwar mid mannum 'everywhere among people' [fol. 57v/22], riht geleafa 'right faith' [fol. 58r/8], unrihta fela 'much unlawfulness' [fol. 57v/22], unriht rihsað 'unlawfulness reigns' [fol. 57v/12]) that help to forge Wulfstan's hammering two-stress rhythm. ${ }^{16}$

\footnotetext{
${ }^{15}$ Function words, such as specific conjunctions - if conspicuously rare in comparison with the entirety of the extant Old English corpus -, may be taken as much more reliable indicators of an individual style. Among these I wish to point out the unusual form oððon (in the meaning 'or'; 'either [...] or') which, in my view, seems to be characteristic of Wulfstan and may be identified exclusively with him. This would bring (parts of) Napier homilies XXXV, L, LIX, and LX potentially closer to Wulfstan's authorship.

${ }^{16}$ On Wulfstan's two-stress prose rhythm see especially McIntosh (1949: 114), who's view is doubted by Masters Hollowell (1982), and reconfirmed by Kubouchi (1999: 47-62) and Orchard (2004). For his exceptionally frequent use of binomials see the studies by Orchard (1992) and Chapman (2017).
} 


\section{Contents}

The two folios contain the following items:

\section{Article I:}

Latin Quotations, fol. 57v/1-3

Two short Latin extracts:

1a) "propheta dicit. Heu heu he[u]. Ergone decipies pop[u]lum istum dicens. pax erit uobis. \& ecce peruenit gladius usq[ue] ad animam" (a rendering of Jeremiah 4:10);

1b) "Idem propheta. Foris interficit gladius. \& domi mors simil[i]s est." (Lamentations $1: 20)$.

The two Latin excerpts in Additional 38651 are desperate and dark in contents and tone, the one from Jeremiah surely not accidentally coming from a chapter in which disaster from the north is at hand for the people of Judah. The other, taken from Lamentations, hints at imminent danger, the sword being out on the street. Both quotations mark the opening to this manuscript and seem to mirror the political climate in which the remaining texts were drafted, indicating Wulfstan's well-known prophetic pose. ${ }^{17}$ The excerpts may have served as a prelude to the now fragmentary article II, as a similar connection with preceding sententiae drawn from Jeremiah has been suggested for the Wulfstan autograph in Copenhagen, Kongelige Bibliotek, Gamle Kongelige Samling $15954^{\circ}$, fol. 66v (Ker 1971: 320; Orchard 2004: 67). ${ }^{18}$ Wulfstan's Latin hand can best be studied in this manuscript and in London, British Library, Cotton Vespasian A.xiv, fols. $171 \mathrm{v}$ and $173 \mathrm{v} .^{19}$

\footnotetext{
${ }^{17}$ One feels reminded of Wormald's (2004: 23) suggestion of Wulfstan being an "Ezra to Cnut's Nehemiah". Orchard rightly points out Wulfstan's affinity for Jeremiah (2007: 314-315).

${ }^{18}$ For facsimiles see Ker (1971: plate VII) and Cross and Morrish Tunberg (1993).

19 Plates of these folios can be found in Mann (2004: 251 and 259). An excellent summary and edition of Wulfstan's Latin sermons is provided by Hall (2004).
} 
More than a thousand Latin quotations, mainly biblical, can be traced in Old English anonymous homilies, where they add authority to the vernacular addresses. ${ }^{20}$ However, the actual compositional and translational procedures concerning the incorporation of these microtexts into the preaching prose often remain obscure. The quotations extracted here could suggest that homilists of the calibre of Wulfstan worked from a framework of thematic sentences during the drafting of their homilies. These micro-text excerpts could be considered as catechetical equivalents to the pericopes of straightforward exegetical homilies. ${ }^{21}$

\section{Article II:}

\section{Homiletic Fragment (WHom 22; ECHOE Homily 130.b), ${ }^{22}$ fol. 57v/5?-27}

A fragment or sketch of a homiletic address by Wulfstan, beginning "[...] ponne swa fela is geworde[n] [...]" (“[...] then so much has happened $[\ldots])$ '.

The text, hitherto unknown, addresses the obligations of men in holy orders and the silence of counsellors, followed by a warning to the English people. Verbal echoes of Napier homilies XXVII, XLVII, and L, and Dorothy Bethurum's homilies VII, VIIIc, Xa, and XXb are unmistakable, but the text is largely independent in its composition and offers a unique insight into Wulfstan's skills of varying and recombining his signature phrases. ${ }^{23}$ Despite the missing ruling, Wulfstan keeps a straight, yet diagonal, left border for the text block, typical for a righthanded person. A longer, mostly illegible annotation (1. 7-16) has been added in the upper left margin thus provided. The right hand margin is notably wide at the beginning of the piece, but is then almost fully used for the main text from lines 16 to 26 . The address may have ended quite abruptly with line 26 , in absence of a concluding doxology, and is followed three lines

\footnotetext{
${ }^{20}$ A comprehensive study of Latin quotations in Old English anonymous homilies by Esther Lemmerz is forthcoming. For the use of Latin in the homilies of the Vercelli Book see Rudolf (2015).

${ }^{21}$ On micro-text references concerning the use of specific pericopes from the West-Saxon Gospels see Lenker (1999).

${ }^{22}$ I suggest "WHom 22" following the recent taxonomy of DOE short titles. I add here the new nomenclature of the digital ECHOE project at Göttingen University, which respects every single manuscript version of a homily by denoting the Ker number and article.

${ }^{23}$ The standard editions are still Napier (1883) and Bethurum (1957). Textual parallels are precisely indicated in the apparatus of the edition below. On Wulfstan's variational technique see, for example, the careful studies by Orchard (1992: 254-258) and Chapman (2017).
} 
below by the isolated scribble $w \hbar$, possibly a signature for "wulfstan bisceop" (1. 29, see Figure 1). ${ }^{24}$

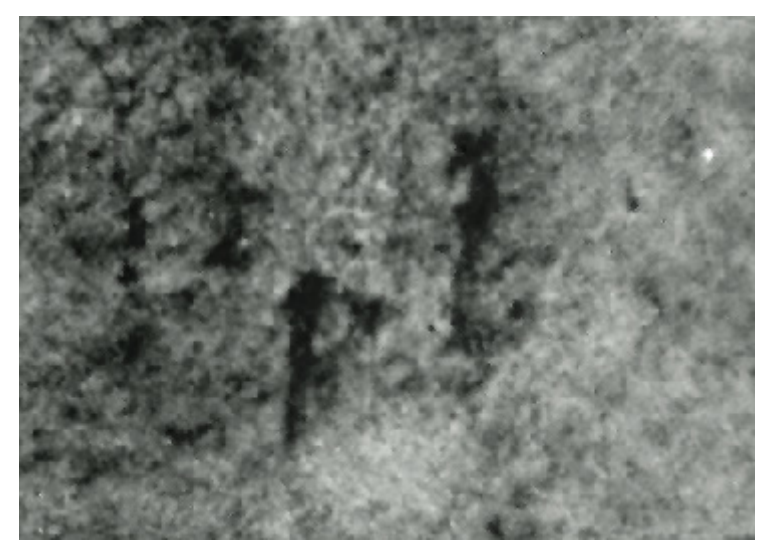

Plate 1: London, British Library, Additional 38651, fol. 57v/29 (detail, multispectral image). Wulfstan's own signature as bishop? (C) The British Library Board 2018.

The text seems too short to have worked as a fully-fledged homiletic address; rather, the inconsistent layout and illegible marginal additions show that Wulfstan was "tinkering with his own prose", as he does elsewhere, according to Andy Orchard (2004: 67). Although the draftlike nature of this micro-text seems clear, Wulfstan's punctuation in this autograph confirms his careful arrangement of clauses, as he often demarcates two-stress phrases. ${ }^{25}$ However, he does not seem to capitalise consistently after punctus versus, a habit common in most fair copy manuscript collections of Old English homilies from the first quarter of the eleventh century. Paradigmatic incremental repetition of thematic words (gebyrian 'to be fitting', unriht 'unlawfulness', bysgian 'to engage', swican 'to deceive', wis 'wise') interlock the prose in which Wulfstan bemoans the decadence of clerics whose foremost duty to fight the injustice in the country would be to pray, study, and teach. The text could have been intended as a compositional unit of a longer preaching address.

\section{Article III:}

\section{Wulfstan's Pastoral Questions for Elfric, fol. 57v/30?-42}

\footnotetext{
${ }^{24}$ Note the pointed belly of the letter $b$ elsewhere in his handwriting. For the common abbreviation $b$ for 'bisceop' see, for example Oxford, Bodleian Library, Auctarium D. 2. 16, fol. 1r/2. Abbreviation or ciphering of one's personal name in order to avoid the sin of vanity is common in Anglo-Saxon England. See for example the name ciphers of Wulfstan's successor Wulfstan of Worcester (d. 1095) and his chancellor Coleman (d. 1113) in Oxford, Bodleian Library, Hatton 113, fols. vi recto and 78v (Ker 1949; Rudolf 2012: 53).

${ }^{25}$ Orchard (2004) has demonstrated the importance of Wulfstan's punctuation for future editions of his works.
} 
A set of questions addressing regulations for bishops and priests concerning the celebration of mass and other matters, with the fragmentary beginning "[...] bes orfes pe for hælinge dead bið [...]" (...of the cattle that dies as a result of castration...).

This unusual list poses its regulatory issues both as nexus and $x$-questions. ${ }^{26}$ Although the verb-subject order in the Mæg man [...] clauses is not peculiar to questions, but occasionally found in positive statements (Mitchell 1985: § 1645), the context here and the punctus elevatus in fol. $57 \mathrm{v} / 36$ strongly suggest that we are looking at a set of interrogative clauses. ${ }^{27}$ The main key to understanding the nature of this unusual micro-text may be found in a Latin Letter by Ælfric addressed to Wulfstan (Whitelock 1981: 247-255), which directly responds to the nine legible issues that occur in this list, such as castration of cattle (VI), saying mass without taking the Eucharist (XI), the use of chrism (VIIII and X), consanguinity (I), the armament of priests (XIIII), the punishment of thieves (XV), blood-eating (VII), and the safekeeping of the Eucharist (XII) ${ }^{28}$ Ælfric himself explicitly refers to questiones sent to him by Wulfstan at the beginning of the Letter (Whitelock 1981: 247), which is dated 1002 to 1005 by Peter Clemoes (1959: 241 and 245) and Malcolm Godden (2004: 354 n. 3). Its total of fifteen paragraphs must also have responded to the now illegible questions drafted by Wulfstan in Additional 38651.

Whilst the close thematic correspondence between Ælfric's Letter and Wulfstan's questions is unmistakable, the divergent ordering of topics in both documents leaves room for speculation on the exact relation between both documents. In my view, this micro-text provides a first draft of those controversial issues that Wulfstan then posed to Ælfric in an official letter, to which the abbot then responded with his Latin Letter. ${ }^{29}$ Both Godden (2004: 354) and Joyce

\footnotetext{
${ }^{26}$ I follow the terminology of Mitchell (1985: $\left.\S \S 1643-1670\right)$ here. Nexus questions in Old English can start with

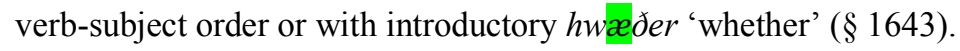

${ }^{27}$ See Mitchell (1985: $\left.\S \S 1643-1645\right)$. Much of the punctuation in the right hand margin has been lost, so that further evidence is lacking. That these lines give titles to longer legal regulations seems unlikely because Wulfstan opens his autograph Old English and Latin titles almost exclusively with $B e$ and $D e$ elsewhere.

${ }^{28}$ Roman paragraph numbers according to Whitelock (1981), which is the standard edition of Ælfric's Letter in view of Fehr's (1914: no. 2a; 222-227) omission of complete sentences. The only surviving version of this letter is found in Boulogne-sur-Mer, Bibliothèque Municipale, 63, fols. 10r-13r (Gneuss and Lapidge 2014: no. 800).

${ }^{29}$ That Wulfstan was already archbishop when he wrote this "lost letter” and how Ælfric's private response must have inspired Wulfstan's commissioning of the other pastoral letters by Ælfric is explained by Whitelock (1981: 242-247). On potential legal controversies, involving Wulfstan's own conduct as archbishop, see Godden (2004: 354-357 and 372-374).
} 
Hill (2004: 313-314 and 2009: 58) have already conjectured on a lost Latin letter by Wulfstan addressing these pastoral issues and we may indeed be looking at the vernacular sketch preparing this document here. It is plausible to assume that the fragmentary beginning (fol. $57 \mathrm{v} / 31$ ? -35) and, arguably, also the top of fol. 58r contained the six remaining issues answered by Ælfric.

Wulfstan must have asked Ælfric's advice in order to be able to respond to problems put to him by his bishops and priests (Whitelock 1981: 244). The legible part of the first question obviously deals with the death of cattle resulting from castration (for hælinge, 57v/33). Ælfric's Letter forbids its consumption, as the meat would have been deemed carrion and unfit for eating. ${ }^{30}$ Saying mass without receiving the host is equally refused by Ælfric ${ }^{31}$ and would clearly contradict Wulfstan's position in his later Canons of Edgar, in which he explicitly forbids priests to do so (Fowler 1972: 11, § 40). Next is a question on the exclusive use of socalled bisceopcrisma 'bishop's chrism' (a hapax legomenon, fol. 57v/36) for baptising on Maundy Thursday, the word certainly denoting the chrism newly consecrated by the bishop in the Maundy Thursday mass as replacement for the ofer geares crisma 'chrism used during the previous year' (fol. 57v/37). ${ }^{32}$ The question on consanguinity in marriage - apart from Ælfric's

\footnotetext{
${ }^{30}$ See Ælfric's Letter (ed. Whitelock 1981: 251): “VI. De castratis animalibus mortuis sit semper turgida caro et virulenta et inflata et feda ad cibos humanos. Et qui decastrat suum animal non ideo decastrat ut moriatur. Quare tunc deputabitur ad cibum, quod non est occisum ad cibum? Nam et canones docent quod si quis abscidat aurem animalis morituri aut aliquod membrum, tamen morticinum erit, nisi vitalis sanguis ex intimis currat foras." - "VI. Concerning castrated animals which have died, the flesh is always swollen and poisonous and inflated, foul as food for humans. And whoever castrates his animal does not castrate it so that it will die. Why then is that which has not been killed for food taken for food? For the Canons teach that if someone cuts off the ear or any other limb of a dying animal, it is still carrion, unless there is life-blood flowing out from the inside.' See further Clayton
} (2002: 268).

${ }^{31}$ See Ælfric's Letter (ed. Whitelock 1981: 249): “XI. Presbiter missam celebrans et non audens sumere sacrificium, accusante conscientia sua, anathema est, quia indignus presumpsit missam celebrare." - 'XI. A priest celebrating Mass and not daring to take the Eucharist, because his conscience accuses him, is anathema, because as an unworthy person he has presumed to celebrate Mass.'

${ }^{32}$ See Alfric's Letter (ed. Whitelock 1981: 250): “VIIII. Omni anno celebrat ecclesia cenam Domini et passionem et resurrectionem et consecrat novum chrisma. Quid debet tibi tunc vetus chrisma cum debes habere omni anno novum?" - 'VIIII. Every year the church celebrates Cena Domini [the Feast of the Lord's Supper] and the passion and resurrection, and consecrates new chrism. Why, then, do you need the old chrism if you should have new one each year?' In his riposte to Ælfric's regulation on the 'Silent Days' before Easter, the Worcester monk Coleman, around the year 1100, indicates that English bishops were customarily carrying out the chrism-blessing and penitential services on Maundy Thursday. See Hill (1985), and Hill (this volume). For the chrism mass in AngloSaxon England and its different types see Jones (2005). 
caustic response (Godden 2004: 354) - also finds answers in corresponding thematic sentences in the later Napier homilies L and LIX, the Northumbrian Priest's Law, and the Laws of Cnut, especially through their echo of the compound neahsib 'kindred, relation' (fol. 57v/38). ${ }^{33}$ In these, marriage is usually forbidden within six degrees of relationship. ${ }^{34}$

Two questions on specific regulations in times of great adversity follow. The first addresses the participation of priests in combat against those who destroy eowdes 7 bu[rga] 'flocks and settlements' (fol. 57v/39), eowdes certainly also to be understood in a figurative sense here. Ælfric clearly argues against this. ${ }^{35}$ The other question addresses the death penalty for thieves, which could have become a major issue as a result of widespread looting. A lenient reaction, as promoted by Ælfric, may no longer have been tenable for some bishops. ${ }^{36}$

${ }^{33}$ See Ælfric's Letter (ed. Whitelock 1981: 247): "I. Satis apparet dilucide in divina scriptura quid sit prima generatio vel secunda vel tertia, et nos minime de hoc dicimus, ne forte dicat aliquis nos dare licentiam aliter coniungendi consanguineos quam sanctus Augustinus et omnes archiepiscopi post eum in hac insula docuerunt." - 'I. It is perfectly clear from Holy Scripture what the first, second, and third generations are, and we are not going to say anything on the subject, lest people go around saying that we give people licence to marry their relatives other than St Augustine and every subsequent archbishop in England have taught them.' See further Napier (1883: 266-74, at 271.8-12 and 307-309, at 308.4-9; Liebermann (1903-1916: I Cnut, 7 and Norðhymbra preosta lagu, 61.1). The subject may nevertheless have been a controversial one (Godden 2004: 354-355).

${ }^{34}$ The variation to four degrees in the Northumbrian Priests Law could be due to miscopying the Roman number VI, but might also add to the argument that Wulfstan is not its author (see Wormald 2004: 12).

${ }^{35}$ See Ælfric's Letter (ed. Whitelock 1981: 252): “XIIII. [...] Qui ad istam militiam pervenit et vult postea secularibus armis uti contra hostes carnales, nonne erit apostata, recedens a militia Dei ad militiam secularem? Ergo non potest in ambabus militiis simul stare, quia illa manus quę humanum sanguinem effuderit non potest digne domini calicem sanctificare." - 'XIIII. [...] Whoever has engaged in this military conflict and afterwards wishes to use secular arms against fleshly enemies, will he not be an apostate, turning from God's service to secular warfare? It is therefore impossible to be engaged in both services at once, because the hand that has shed human blood cannot worthily consecrate the Lord's chalice.' The Laws of Elfred prescribe excommunication of priests who kill (Liebermann 1903-1916: Elfred, 21). For the emendation bur [ga] see also Lambeth Homily 2, which is partially based on Wulfstanian texts (Morris 1868: 12-13): “[...] eower burh heo for-bernað and ehee [read: ehte] heo aspillað [...]" - '[...] and your cities shall they burn and your goods they shall destroy $[\ldots]$ '.

${ }^{36}$ See Ælfric's Letter (ed. Whitelock 1981: 253): "XV. De furibus. Non est episcopus constitutus ad hoc ut sit iudex furum aut latronum. Et si mihi non credis, audi verba Christi [...] Seculares iudices debent iudicare de furibus et latronibus, quia canones prohibent episcopos uel clericos de his iudicare. [...] Sed ualde dolendum est, quia his diebus tanta neglegentia est in episcopis qui deberent esse columpne aecclesiae [...]." - 'XV. On thieves. A bishop is not appointed so that he may be a judge of thieves and robbers. And if you don't believe me listen to the words of Christ. [...] Secular judges have to judge on thieves and robbers, because the Canons forbid bishops or clerics to judge on them. [...] But it is greatly to be deplored that in these days there is such great negligence among the bishops who ought to be the pillars of the church [...].' One feels reminded here of Ælfric's Life of Edmund in 
Wulfstan's use of we in this sentence (fol. 57v/40) - if not a pluralis maiestatis - could indeed include other bishops and the correction \nu/ we heom elles gestyr[en] ne m[agon] ' $I$ now/ that we cannot restrain them otherwise' ( $n u$ written over an erased gif 'if'!) suggests a serious failure of the current legislation to which the archbishop might have wished to respond by increasing the severity of the punishment. Ælfric's idealistic position, bishops not being judges, is clear, but Wulfstan's perhaps less so, given Ælfric's almost indignant et si mihi non credis 'and if you do not believe me' (Whitelock 1981: 249) in his Letter. ${ }^{37}$

To the question on the eating of blood (fol. 57v/41), related to the above regulation on carrion cattle, Ælfric replies with general prohibition. ${ }^{38}$ Still, the subject may have remained an important issue, because coagulated blood could be turned into a variety of nourishments and many of these may have found (new) friends in times of here 7 hungor (fol. 57v/20).

The last question on folio $57 \mathrm{v}(1.42)$ centres on the safekeeping of winbread 'winebread', another hapax legomenon), about whose meaning in this context one can only speculate. The most plausible explanation might be a regulation on the commixtio of the Eucharist, which was received in both forms in the tenth and eleventh centuries. ${ }^{39}$ The hapax could, for example, signify the mixed Eucharist left over after mass, often intended for the sick by scraping bread

which the bishop feels remorse after having hanged the thieves that attempted to break into Edmund's tomb (Skeat 1966: 314-334, 1. 214-231). On varying punishments of theft see also Wormald (1999: 305).

${ }^{37}$ See also Barrow (2004: 143-144) and Godden (2004: 354-356), who reads the Latin Letter as a decided criticism of the newly elected archbishop. See also Whitelock (1942: 25-45).

${ }^{38}$ See Ælfric's Letter (ed. Whitelock 1981: 249): “VII. Sanguinem cum terribili comminatione prohibuit Deus in cibos sumere Noe et filiis eius et similiter in lege Moysi, quia sanguis vita pecorum est, et omnis qui sanguinem commederit, delebitur de populo suo, [...]. Sed dicunt quidam non esse sanguinem cum coctus fuerit. Et nos dicimus e contra: quia cocta caro caro est. Coque ovum aut assa! Quid erit cum coctum aut assatum fuerit nisi ovum? Et cuius nature est coctus sanguis nisi sanguinis? Quis homo vult manducare aut bibere crudum sanguinem? Animadverte ex hoc Deum non prohibere hominem a crudo sanguine tantum quantum a cocto." - 'VII. With a dire threat God forbade Noah and his sons to eat blood in their food, and likewise in the Law of Moses, because blood is the life of the cattle, and anyone who has eaten blood shall be cut off from among his own people. [...] Some people say it is not blood if it has been cooked. But we say to the contrary: even boiled flesh is still flesh. Boil an egg or fry it! Fried or boiled, what else would it be but an egg? And what by its very nature is cooked blood but blood? Who wants to chew or drink raw blood? What you must understand from this is that God does not forbid man from eating raw blood any more than cooked blood.' See also Bethurum homily Xc (1957: 205.104-105).

${ }^{39}$ The synods of Clermont (1095) and London (1175) strongly advocated the full communion, but tolerated the intinctio for the sick and for children. See $R G G$ s.v. Kelchentziehung. For the habits of commixtio see Amalarius of Metz, De ecclesiasticis officiis (PL 105, col. 1152), also Fortescue (1950: 366-368) and Klauser (1979: 6667). For Wulfstan's liturgical interests and his use of Amalarius in his ‘Commonplace Book' see Jones (1998) and (2004). 
into the emptied chalice after the intinctio. The sacrament could then be kept in the emptied vessel. ${ }^{40}$ Section XII of Ælfric's Latin Letter, if indeed related to this question of Wulfstan's, seems to suggest that this was permitted, keeping in mind that consecrated hosts had to be kept in metal receptacles exclusively. ${ }^{41}$ Considering Ælfric's denial of double consecration in this section, the regulation could more specifically concern the communion on Good Friday, using consecrated bread of the Maundy Thursday mass and mixing it with unconsecrated wine. ${ }^{42}$ Ælfric adds specific instructions on the intinctio and communion on Good Friday in his second Old English Letter to Wulfstan (Fehr 1914: no. 3, 164-167, esp. §§ 50-54) which suggest that no further consecration was carried out on Good Friday. ${ }^{43}$

Overall, this list of Wulfstan's prepared for Ælfric contains debatable legal issues that concern the general availability of foodstuff, warfare, and theft, all of which must have been particularly relevant in times of a political crisis. ${ }^{44}$ The text of article III does not seem to have continued on what is now the blank top of folio 58r, but it cannot be entirely ruled out that questions answered by Ælfric in his Letter were written there or on missing bifolia of a potentially larger booklet.

\section{Article IV:}

A Version of Napier Homily XXV (HomU 24 [Nap 25]; ECHOE Homily 130.d), fol. 58r/6$58 v / 3$

\footnotetext{
${ }^{40}$ See Ælfric's Letter (ed. Whitelock 1981: 251): “XII. Qui bis unum sacrificium consecrat, similis est illi qui unum infantem bis baptizat et uterque anathema est. Et cavendum est nimium ut sacrificium quod pro infirmis tenetur ne tam diu teneatur ut putrescat aut mollescat aut nigrescat aut a muribus aut avibus sumatur." - 'XII. Whoever consecrates a Eucharist twice, he is like the one who baptises a child twice and both things are anathema. And it is very much to be avoided that the Eucharist for the infirm be kept too long in such a way that it rots, softens or molders or that it should be consumed by mice or birds.' On the habits of preserving and giving the Holy Communion in the eleventh century see Browe (2003 : 303, 317-319, 383-389).

${ }^{41}$ See Fowler (1972: § 41).

${ }^{42}$ Dunstan of Canterbury authorized the giving of Maundy Thursday Eucharist in the Good Friday service ( $P L$ 137, col. 491), while Amalarius seems to have assumed that the Good Friday wine was consecrated through simple intictio (PL 151, col. 989). See also Browe (2003: 318-19).

${ }^{43}$ Fehr (1914: 166-167, §53 [O]): "Do se mæsse-preost ponne of pam husle mid swygan into pam calice.” - 'The priest should then put a part of the host into the chalice.'
}

${ }^{44}$ See Fehr (1914: 222-227). 
A homily beginning "Leofan men understandað geornlice hu [m]icel pearf is cristenum mannum [...]" (Dearly beloved, understand eagerly how great the need is for all Christians [...]), largely paralleling Napier's homily XXV, with an independent middle section and an ending echoing phrases in Bethurum homilies III, VI, and VIIa. ${ }^{45}$

The middle part of this short homily expands on the obligation of priests only to baptise those adults who show the signs of true belief and an evident willingness to learn about Christianity. The phrase lyt we [magon] fullian pa man 'we may hardly baptise the man' (fol. 58r/19) speaks to bishops and priests, although the entire homily must have been addressed to a wider audience on account of the concluding doxologies. This could have led to the later omission of the middle section, if we assume that we are looking at Wulfstan's autograph draft of Napier XXV. The idea may not seem too far-fetched when we consider the unusual layout of folio 58r. After the opening line Leofan men understandað geornlice hu 'Dearly beloved, understand eagerly how' (fol. 58r/6), which runs to about mid-page, the entire text block following is indented. The capital $M$ which begins the Micel pearf is cristenum mannum 'There is great need for all Christians' of line 7 suggests that the preceding line with the opening was added later. The upper empty margin of folio 58r could indicate that Wulfstan intended to add a longer thematic unit in this space as a beginning or that such a unit indeed existed and was subsequently erased. The wide left margin was probably left to facilitate addition, variation and correction, while indeed some text, almost completely illegible now, has been added at line 18 . The main text seems to have continued to the top of folio $58 \mathrm{v} / 3$, as some faint traces of writing indicate. All known versions of Napier XXV show expansions not present here, the variants in Cambridge, Corpus Christi College 201 and Oxford, Bodleian Library, Hatton 113 standing notably closer to Additional 38651 than London, British Library, Cotton Tiberius A.iii. ${ }^{46}$ Patrick Wormald (2004: 26) dates the original composition of Napier XXV - assessing only the manuscript versions known so far - to the years 1005-1006.

\section{Conclusions}

\footnotetext{
${ }^{45}$ For the exact textual parallels see the edition below.

${ }^{46}$ See Napier's apparatus (1883: 122-124) and the edition below. A full non-hierarchical edition of all manuscript versions of Napier homily XXV will be provided by the ECHOE project.
} 
The document as a whole suggests that we are looking at Wulfstan's personal drafts and notes, gathered as a collection of micro-texts that could have served him not only in the composition of fair copies of homilies and letters but also in his preaching duties as bishop and archbishop. The unusual layout with its wide margins for the homiletic pieces (articles II and IV), the additions, erasures, and autograph corrections show us the bishop as an active, eclectic composer and reviser of homilies, while the legal questions in article III reveal Wulfstan's method of letter-drafting and seem to mark the "cool and critical" (Godden 2004: 372) beginning of his collaboration with Ælfric. The legal issues posed here form the basis of Ælfric’s later Pastoral Letters (Whitelock 1981: 255-302; Fehr 1914: 146-221), which, in turn, became indispensable for the composition of Wulfstan's own canon law collections. ${ }^{47}$ The texts raise numerous questions on the practical reasons for Wulfstan's collection of legal problems, on the exact relation and collaboration between him and Ælfric, ${ }^{48}$ and on Wulfstan's preaching practice, both written and oral, all of which deserve future exploration.

Patrick Wormald (2004: 11-12) rightly refuted Christopher Hohler's (1975: 225 n. 59) claim that "the man who asked Ælfric for his Pastoral Letters can hardly himself have been a canonist; and most of his life must in any case have been spent not in the library, but in the saddle". The manuscript evidence of Additional 38651 adds some evidence to Wormald's argument and shows the archbishop at his desk, working as a creative writer and reviser of his carefully sketched drafts, as well as a correspondent of Ælfric (then of Cerne). Nevertheless, the shape and material of Additional 38651 may suggest a portable notebook in practical format, which could also have served Wulfstan well in his active, and surely mobile, campaigning for law and order as bishop of both Worcester and York. Revisions to the preaching texts in this document might have been carried out by Wulfstan on the job. Especially the homilies could thus be tested and improved prior to fair copying and further dissemination. In other words: Wulfstan acted both as an active travelling preacher and an erudite and expertly advised composer of homilies and law codes.

The fascinating juxtaposition of homiletic and legal matter in Additional 38651 strongly recommends that a strict segregation between Wulfstan's preaching texts and laws, as undertaken by Bethurum, cannot be reasonably defended. ${ }^{49}$ Wulfstan would finally act as a catalyst between the gospel and the law (Stanley 2004), a role that Ælfric encouraged much

\footnotetext{
${ }^{47}$ On the influence of Ælfric's letters on Wulfstan's collection of canonical law see Cross and Hamer (1999: 1722).

${ }^{48}$ Godden (2004) and Gneuss (2009: 28).

${ }^{49}$ Fowler (1972: xxix-xxxiv), Wormald (2000: 205-206 and 2004: 16-17), Orchard 2007: 323.
} 
through his letters. Article III no doubt witnesses one of Wulfstan's very first attempts at working towards consolidated canons and law codes during some of the most difficult years of Æthelred's reign, in dialogue with Ælfric's idealistic, scripture-based demands. This was surely not the easiest of tasks. The content of the two homiletic pieces (articles II and IV) also responds well to this historical context, although the version of Napier XXV - missing some of the rhetorical bite of its parallels - very probably predates the fair copy witnesses we have known until now. Within the chronology of Wulfstan's works the texts contained here may therefore, in my opinion, best be dated to Wulfstan's later London years (articles I and II) and the initial period of his episcopacy at York and Worcester (articles III and IV), so to $c$. 1000-1005. ${ }^{50}$ This chronology hinges to some degree on the interpretation of Wulfstan's title of a 'bishop' in the potential signature on folio $57 \mathrm{v}$, assuming that the pieces following it in the manuscript were drafted later. The signature could reflect Wulfstan's rank as bishop of London (996-1002), and thus help to date articles I and II to this period, yet would exclude articles III and IV, which would then fall into his early days as archbishop at York (see also Whitelock 1981: 242).

The manuscript features of Additional 38651 and its micro-texts should remind us that many of our surviving homiletic manuscripts represent fair copies of elaborately composed preaching addresses whose working drafts are almost always lost today. Yet it is clear from the surviving manuscript evidence that even larger collections produced from these drafts could not resist the addition of further revisional and performative interventions of later revisers. These revisers must have been fully aware of the fact that many Old English homilies are indeed composite texts, constructed from quarry pieces that could have existed as separate micro-texts during the intermediary stages of text composition. Additional 38651 should be celebrated for its unique status as an autograph witness to the creative processes of preaching and law-making in late Anglo-Saxon England, in which Wulfstan, Archbishop of York, was to excel in the years to come and through which he would exert a lasting influence on English legislation, for two more centuries at the least. ${ }^{51}$

As for Wulfstan's autographs, we now have a good deal more writing in his own hand available on the basis of which some more definitive conclusions can be drawn on his personal style and working method. It is most important to note Wulfstan's role as creative composer and reviser in the homiletic pieces of Additional 38651, activities which underscore his

\footnotetext{
${ }^{50}$ On the chronology of Wulfstan's works see Wormald (2004: 26-27). He dates the beginning of Wulfstan's legislative campaign to about 1006-1008 (2004: 16). See further Fowler (1972: xxix) on homilies of practical instruction and their relation to the Canons of Edgar.

${ }^{51}$ Wormald (2004: 21-25) offers a passionate appraisal of Wulfstan's importance for the history of government.
} 
privileges as bishop and archbishop with regard to homiletic composition. ${ }^{52}$ The micro-texts preserved here, both in their macro-structure as potential building-blocks for longer addresses and in their micro-structure of 'phrase-tinkering', confirm in autograph form for the first time that his compositional strategy was thoroughly eclectic and creative, as characterised by Tristram (1995: 8), Orchard (2007) and others. That later homilists would take both his style and method as a role model is therefore no surprise. ${ }^{53}$ To speak of 'imitators' of Wulfstan's style, however, means to fall for anachronistic concepts of authorship and originality and miss the point. ${ }^{54}$ What Wulfstan himself was used to doing to his own writings as well as those Latin and Old English ones of Abbo of St-Germain, Atto of Vercelli, Pirmin of Reichenau, or Ælfric (no one has ever called Wulfstan an imitator of him) ${ }^{55}$ was perfectly acceptable to vernacular homilists after him, as long as they adhered to the Augustinian instructions in De doctrina christiana for the composition of their addresses (Green 1995: 280, xxix.62 and Tristram 1995: 23-28). Wulfstan must therefore be credited with the development of an already established eclectic compositional method and with an exceptional rhetorical mode of preaching whose later adoption and variation by others attest to its effectiveness. It may even have become obligatory to compose and deliver catechetical addresses in this form, given Wulfstan's archiepiscopal authority of his later years. ${ }^{56}$ The style and its original variations, not all of which need be Wulfstanian (Scragg 2005: 7-23), quickly became an authoritative technical idiom of later homilists and ensured Wulfstan's legal and homiletic œuvre as an influence on English society until decades after the Conquest (Wormald 2004: 23-25). Additional 38651 witnesses literally 'first hand' the defining processes of this idiom. ${ }^{57}$

\footnotetext{
${ }^{52}$ On the episcopal privilege of homiletic composition in the mid-eleventh century see for example William of Malmesbury's Vita Wulfstani (Winterbottom and Thomson 2002: I.8).

${ }^{53}$ See especially the important studies by Scragg (1977 and 2005).

${ }^{54}$ The concept was introduced by Jost (1950: 114-116) and has been entertained by Orchard (1992: 257), Scragg (2005: 22), Ogawa (2010: 15 and 59) and others.

${ }^{55}$ On the sources of Wulfstan's writings see, for example, Jost (1932), Fowler (1972: xxxiv-xlv), Cross (1992 and 1993) and Orchard (2004: 71). Detailed discussions of Wulfstan's use of Ælfrician material are provided by Godden (2004: 362-370), and also Zimmermann (1888: 26-35), Jost (1950: 117-29, 129-131), Orchard (1992: 259-64) and Kubouchi (1999: 37-46). On Ælfric's potential abhorrence at Wulfstan's reuse of his works see Godden (2004: 373).

${ }^{56}$ On Wulfstan teaching his own catechism and educational method to his bishops and priests see the excellent study by Wilcox (2000).

57 That Wulfstan's idiolect was limited, as argued by Orchard (2007: 321), would only facilitate later expansion.
} 
Concerning the question of 'original Wulfstan', in light of this newly retrieved, most comprehensive known autograph of his, it must be clear that 'originality' is a criterion that is hard to define with regard to a missing contemporary Anglo-Saxon concept for the vernacular writings that draw so extensively on Latin sources. It is even harder to define for a genre of such abundant textual fluidity as reusable vernacular preaching texts, because here the eclecticism of sources is further complemented by the multiple revisional layers found in the range of manuscript witnesses (Wright 2007) that survive today. Given this fact, we should restrict the label 'original Wulfstan' to the autographs and treat the question of his authorship and canon, as well as future editions of his works, in a more appropriate way, namely one that accepts and respects the medieval conventions of genres of textual reuse. Wulfstan probably authored more works than hitherto acknowledged, but many of these texts would defy a hermetic textuality, thanks to other revisers and, not least, to Wulfstan himself. ${ }^{58}$ In other words: even though we often do not know how much Wulfstan exactly a particular homily still contains, the search for it should no longer be such a field-defining issue with regard to the changing, yet co-existing, textual identities of Wulfstanian pieces in their varying manuscript contexts. $^{59}$

Finally, we should be fully aware that the identification and subsequent celebration of an author such as Wulfstan usually supports the construction of a literary canon, which is, in turn, prone to manifest national identity. Yet a national literary canon was surely as alien a concept to an Anglo-Saxon archbishop who made ample use of European sources as it should be alien to scholars today to misappropriate Wulfstan for such a purpose. This does not mean to belittle Wulfstan's exceptional merits in any way, it only asks for novel ways of evaluating and appreciating his literary impetus and impact. His autographs will provide plenty of opportunity to do so in the future.

\section{$6 \quad$ Text}

\subsection{Editorial Procedure}

\footnotetext{
${ }^{58}$ I agree with Wilcox (1992) and Wormald (2004: 17).

${ }^{59}$ See for example the discussion of Bethurum's homily VII (1957: 157-165) by Orchard (1992: 255).
} 
I have used the best images merged from a set of multispectral and UV scans (see Figures 2-5 on pp. $\square$ provided by the British Library. A great deal more of the text is legible now, but due to erasure and damage numerous gaps with sometimes only very vague traces of letters remain, even after the use of investigative photography and subsequent processing of images through canny edge detection. These gaps are marked as [...], regardless of their length. In some cases it is nevertheless possible to find secure readings of almost illegible traces and establish plausible emendations of almost completely lost text in dialogue with the DOEC and the known manuscript versions of texts commonly associated with Wulfstan. I have marked all emendations in square brackets and interlinear insertions with backslash and slash. Round brackets signal mere conjectures on little more than the faintest traces of letters. They should be treated as such and might well be improved by future research and better technology. The letters $s$ (in its variant forms) and $p$ have been normalised; abbreviations, except for the Tironian note, have been expanded. Punctuation corresponds to Wulfstan's use of the medial simple point and the punctus versus, although it is very difficult to recognise every instance of punctuation due to limited legibility.$^{60}$ I have decided to transcribe diplomatically, setting line numbers according to space rather than text, by measuring average line height, because it is simply impossible to rule out that lost or now illegible text of some kind may have existed in seemingly empty spaces on the folio. Line numbers should also help the reader to judge the relative original length of the fragmentary texts. The apparatus combines information on the layout and scribal procedure with references to textual parallels and echoes in other known texts associated with Wulfstan. I refrain from a critical apparatus for article IV here, because the evident textual mouvance and variance of Old English homilies is best studied and analysed through digital editions that respect the single manuscript versions in their own right, in defiance of an idealised text. ${ }^{61}$ All translations are my own and include reconstructed text whenever deemed plausible.

\footnotetext{
${ }^{60} \operatorname{Ker}$ (1971: 318-319), Orchard (2004).

${ }^{61}$ Apart from the corpus of anonymous homilies, the ECHOE project at Göttingen, funded by the European Research Council, will provide a new digital edition of the homiletic writings of Wulfstan, enabling the flexible textual comparison with any of the existing parallel versions of the known corpus. - I am most grateful to Thomas N. Hall, Susan Irvine, Richard North, Stephen Pelle, Peter Rudolf, Donald Scragg, Jonathan Wilcox and the editors of this volume for their helpful comments on this paper. Finally, I wish to express my deep gratitude to Stephen Norman Tranter (1951-2007) who first introduced me to Wulfstan and aroused my interest in Anglo-Saxon homiletics. His memory will live on.
} 


\section{AN DIE SETZEREI:}

Die untenstehenden Textteile, bestehend aus

- altenglischem Lückentext (6.2 Edition)

- neuenglischer Übersetzung

- Anmerkungen (“Apparatus")

bitte wie folgt anordnen (s. separates Musterdokument):

- altenglische Text: linke Seite

- neuenglische Übersetzung: rechte Seite

genau gegenüber, mit den gleichen Zeilennummern jeweils auf gleicher Höhe;

- Anmerkungen (“Apparatus” zu folios 57v und 58r)

wie Fußnoten am Seitenende unter die Text- und Übersetzungsteile mit den entsprechenden Zeilennummern drucken (d.h. immer nur so viele von den Anmerkungen auf der jeweiligen Seite unten einfügen wie oben Text mit der gleichen Nummerierung zu stehen kommt).

Wir hoffen, dass sich beim Satz in petit keine Zeilenumbrüche ergeben. Falls diesbezüglich oder auch im Hinblick auf die Gesamtanordnung der Teile nach den „Works Cited“ Probleme auftreten, bitten wir um Rücksprache mit Frau Kuchta und uns Herausgeberinnen.

Die Platzierung der Wörter und Wortteile dort, wo es sich um einen Lückentext handelt, wie unten in der Manuskriptvorlage umsetzen.

Die zusätzlichen Leerzeichen/Abstände in „Apparatus, folio 58r““ zu Zeile 35 bitte beibehalten.

\subsection{Edition: London, British Library, Additional 38651, fols. 57v-58v}

\section{/57v/ (flesh)}

1 propheta dicit. Heu heu he[u]. Ergone decipies pop[u]lum istum dicens. pax erit

2 uobis. \& ecce peruenit gladius usq[ue] ad animam

3 Idem propheta. Foris interficit gladius. \& domi mors simil[i]s est.

ðæt

$8 \quad(\mathrm{Ea}) \mathrm{la}[\ldots](\mathrm{m}) \mathrm{a}[\ldots]$ (weorðan on) $[\ldots]$. ponne $\mathrm{s}[\mathrm{w}] \mathrm{a}$ fela is geworde[n] (binnan) $[\ldots]$

9 (li)f f(æder) $[\ldots]$ (s) $[\ldots]$

(ahsi)ge wæ[...]

10 (O)n u(res)[...] (forð[...]fæder don) [...] ælces hadesm[a]n. oððon he wold[e.] oððon]

11 he scolde. poet lufian poet [h] is hade to gebyrede. ac nu gehwa oððon nele

12 oððon ne mot ne ne mæg; forpam ælc unriht rihsað. swa forð on 
pysse beode swa æfre ær dyde; gehadedum mannum gebyrede

14 swyðe [...] poet [h]y hy abysgedon. dæ[ges 7] nihtes. mid gebedum 7 mid bocum.

15 oft 7 gelome. 7 pæt hy be[mæ]nedan $7 \mathrm{~g}$ [eorn]lice læran[;] ac $\mathrm{n}[\mathrm{u}]$ hy man

16 bysgað mid oðrum pingum $[$.$] ealles to s[wyðe]. [...]gan hy for [...]ld [...]$

17 (swa) (hyr)an gode. swa swa hy [sco]ldan. 7 (eac) (on) [...] be hy (bæs) [...]

$18[\ldots]$ (pa) [...] is on pysse peode(.) piniende swyðe. 7 swicdom is [swið]e 7)[...] (mod) wisast[an]

19 [wi]tan syndan swige[.] 7 [...] geswic[an] syndan swiðe pe[arle] [...]ende. Nu

20 (forpam) is pes peodscipe $[\ldots]$ að of $[\ldots]$ de. $\mathrm{h}[\ldots$ For]pam is ons[æ]ge here 7 hungor. bryne 7 $\mathrm{b}$ [lodgite.

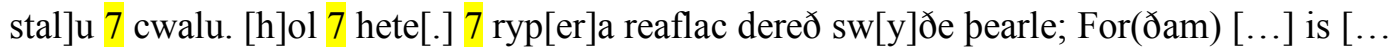

...] is swa hit pincan mæg[.] unrihta fela. 7 [tealte] getrywða. æghwar mid mannum [g] ehwyl[cum. ...

...]ne. 7 py is on lande fals [n]eah. 7 fracoð(es) [...] (lice) gemetu (nu) ge[...]. (Fela syn)

$\mathrm{f}[$ or] sworene. 7 swyð[e] forlogen[e. 7] wed abr[o]c[e]n[e]. oft 7 gel[o]m[e.] [...]syndon f[...

...] tal[i]að hy sylfe wære 7 wise[.] fo[r gode 7] for worolde[;] Ac wac bið se wisa[...] (be) [... ...] (hine) [...] wær[ast] 7 wisast[;] E[a][[a] fe[1]a) unrihta d[e]reð pysse $\mathrm{b}[\mathrm{e}]$ ode.

pes orfes pe for hælinge dead bið. gif we for $[\ldots] ð(\mathrm{p} c e t)[\ldots]$

36 Mæg man mæssian 7 husl ne picgan; Mæg man fullian mid biscopcrisman.

37 on punres dæg ær eastran[.-] 7 hwy ne mot man notian ofer geares crisman.

38 On hu neahsibban man wifian mote 7 hwæt sy prima progenies. Igeneratio/ hwæt secund[a.]

39 hwæ[b]er w[e] motan gefeo[ht]an for $\backslash($ of)/ neade wið pa pe aspillað eowdes 7 bu[rga.-]

40 hwæper we motan peofas hatan slean[.] nu we heom elles gestyr[en] ne m[agan.-]

41 Hwæper man mote blodes brucan. gif hit bið to mete gemacod. 7 ealswa (drince.-)

42 Mæg man winbread on cælic sca[f]an. butan man elles win hæfed[e.-]

[Apparatus folio 57v: ohne diese Überschrift wie Fußnoten am Seitenende unter die Text- und Übersetzungsteile mit den entsprechenden Zeilennummern drucken] 
1-2 An abridged quotation of Jeremiah 4:10.

3 See Lamentations 1:20.

6 A pen trial? Traces of a header?

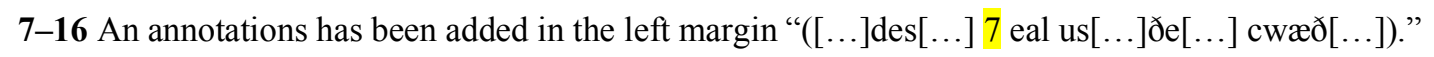

9 The text extends far into the right margin here, possibly due to an addition.

12 unriht rihsað] cf. Bethurum homily V (1957: 136, 1. 30).

13 gehadedum mannum gebyrede] cf. Bethurum homily VIIIc (1957: 175, 1. 4-5).

14 mid gebedum 7 mid bocum] cf. Napier homilies XXXVII (1883: 179.6) and LIX (1883: 307.12).

16-26 The text extends into the right hand margin here.

19 syndan swige] For the unusual use of swige with a form of beon cf. Bethurum homily Xa (1957: 193.48-49).

20-22 Forpam ... mannum] cf. Napier homilies XXVII (1883: 129, 1. 1-7), XLVII (1883: 243.1-4) and L (1883:

268.21-26).

21-22 Forðam ... mannum] cf. Bethurum homily XXb (1957: 263, 1. 67-69).

23-24 Fela ... gelome] cf. Napier homilies XXVII (1883: 129, 1. 7-8) and L (1883: 268, 1. 26-28).

25 wac bið] cf. Bethurum homily VII (1957: 157.6).

29 A signature reading "Wulfstan bisceop"?

30 Traces of a header?

39 eowdes 7 burga] cf. Lambeth homily 2 (Morris 1868: 12-13).

$40 \mathrm{nu}$ ] on erasure [:gif:].

42 For the spelling scafan for OE sceafan 'to scrape’ see Brunner 1965: § 92.2d and Cockayne (1864-1866, II, 174-298, 64.3.2).

/58r/ (flesh)

1

(leofan)

2

3

4

5

6 Leofan men understandað geornlice hu

Micel pearf is cristenum mannum. poet hy heora fu[lluhte]s gescad w[it]a[n.]

7 bæet hy rihtne geleafan cunnan. 7 pæ[ne fæ]strædlice [healdan; Forðam] nah \ænig/man afull[ian]ne hæðenne [ma]n. gyf [he ylde 7 andgyt hæfð.] pcet he geleornian mæg hwæt ful[luht mæne 7 geleafa sy. ne huru ær he gele]ornige. pæet [he] wite [eal hwæt] hit beh[eald]e; [a]c syðp[an] he bi[ð] ful[luht]es [wy]rðe. s[y]ððan [he] mid rih[t]an gele[afan hit] wel [understandeð]. ponne ag[an pa] micle pearf[e] pe [o]n [geog]oð[e] gefull[ode weo]rð[a]ð. peet hy georn[e leo]rnian[.] syðð[an $h] y$ pa y[lde] 7 poet andgyt habban. poet hy [leo]r[nia]n magan. [7 poet hy magan understandan] rihtan geleafan. 7 poet [hy] heora ful[luhte]s gescad 
[wit]an[.] pe (man pe) næfð rihtne geleafan. [he ne gefærð naht bu] $\tan [$ he] geleornige. pat he hine cunne. 7 hine syððan gl[æd]lice healde. lyt we [magan] fullian pa men pe his cristendo[mes ge]sc[ad] nat. ne geleornian nele. pet [he] his gescad wite[;] Forð[am] beter[e] him wære pat he [næ]fre [ge]wurde. mænnisc m[an] ponne he gewurde. se be ne[le] his cristendomes hedan; Leofan [men] pat he his gescad wite. lac/ poet bið cristenes mannes pearf poet he [smeage] 7 ahsige[::]georne. hu p[eo]s worold. ærost gewurde; [7 swa] forð pæt he wite. hu crist to mannum come. $7 \mathrm{hu}$ he for us deað prowode. 7 hu he o[f] deaðe [aras.] $7 \mathrm{hu}$ he to hefenum astah. 7 hu he panan [e]f[t to pam] miclan dome cymð pe we ealle to scylan. [On pam] dome he eowað us his blodigan sidan. 7 [his pyrlan] handa. 7 pæne pyrnenan helm. 7 pa sylfan [rod]e(.) pe he for ure neode. on ahangen wæs[.] 7 wile bo[nne] anrædli[ce wi] tan æt us. \o[...]/ 7 hu we urne cristendom gehealden habban. wel pam ponne pe hine wel geheald[en hæfo.] 7 wa $\mathrm{p}[\mathrm{a} m]$ bo[nne] p[e] his [ær] gyman nolde(.) swa [swa he sceolde.] Ac [uto]n forpam don swa swa us micel [pea]rf is. helpan ure sylf[ra pa hwile pe] [w] e magan 7 moton. 7 habban aa rihtne geleafan 7 [...] pe læs we forweorðan ponne we læst wenan[.] $\mathrm{U}[\mathrm{t}]$ on lufian godd ofer ealle [oðre ping. 7 his wyllan wyrcan. swa

[Apparatus folio 58r: ohne diese Überschrift wie Fußnoten am Seitenende unter die Text- und Übersetzungsteile mit den entsprechenden Zeilennummern drucken]

1-5 Extremely faint, illegible traces of writing on the multispectral image.

1-11] cf. Bethurum homily VIIIc (1957: 175.1-10).

$6 \mathbf{~ h u}$ ] The word is followed by a sloping stroke, connecting the end of this line with the beginning of the next, thus connecting the two into one sentence, despite the capital $M$ of micel.

7 Micel] The first leg of the capital $M$ shows some decoration descending to the line below. From this point onwards the text block up to the bottom of the page (1. 7-38) has been indented by c. $30 \mathrm{~mm}$ in comparison to the opening line 6.

7 cristenum] on erasure.

11 ne huru ar he geleornige] A variant paralleled only by the CCCC 201 and Hatton 113 versions of Napier homily XXV (1883: 123 n. 5).

17 In the left margin "forpam".

19 healde] The parallel with Napier homily XXV (1883: 122.12-123.11) ends here. 
21 betere ... he gewurde] cf. Bethurum homily III (1957: 126.69-70).

23 ac] The parallel with Napier homily XXV resumes here (1883: 123.13). This section on the creed also occurs as the final part of the Hatton 113 version of Napier homily I (1883: 4 n. 4).

24 ahsige] on erasure [:smeage:].

28 In the left margin “[...]æs hæfð/[...]”.

28-33 cf. Bethurum homily II (1957: 121.65-69) and Napier homily XL (1883: 189.11-15).

35 Wulfstan's hand becomes smaller here. Ac] Probably a later addition in the left margin (cf. the insertion on fol. 58r/23). Ac ... moton] cf. Bethurum homily III (1957: 126.74-76. pearf is] The parallel with Napier XXV stops here (1883: 124.11).

367 habban aa rihtne geleafan ... amen] cf. Bethurum homily VIIa (1957: 168.45-49).

37 The line has been indented by about $30 \mathrm{~mm}$. pe ... amen.] cf. Bethurum homily III (1957: 126-127.76-80.

38 The second half of the line has been trimmed.

\section{/58v/ (hair)}

1 we] (ge)[ornost magan. ponne geleanað he hit us swa us leofast bið

2 ponne] (we) [æfre pæs betst bepurfan. Him symle sy lof 7 wuldor

3 in ealra worulda woruld a butan ende. amen.]"

\subsection{Translation}

\section{Article I: Latin Quotations, fol. 57v/1-3}

1 The prophet says: "Alas, alas, alas, do you therefore deceive this people, saying "peace shall be

2 among you'? For behold, the sword has reached even to the soul."

3 The same prophet [declares]: "In the street the sword kills, in the house it is like death."

\section{Article II: Homiletic Fragment (WHom 22; ECHOE Homily 130.b), fol. 57v/8-26}

$8 \quad[\ldots]$ then so much has happened $[\ldots]$

10 every member of an order, if he wanted to or

11 must, love that which would befit his office, but now everyone either does not want to,

12 must not or cannot. Therefore every unlawfulness reigns forth among

13 this people, as it ever did before. Ordained men should be very much obliged

14 that they occupy themselves by day and night with prayers and with books,

15 often and frequently, and that they lament and eagerly teach. But now they

16 busy themselves with other things all too much. [...] they for this $[\ldots]$

17 God as they should and [...]

18 is severely tormenting this people. Deceit is severe $[\ldots]$ the wisest

19 counsellors are silent and $[\ldots]$ offences are very grave $[\ldots]$. Now 
20 [therefore] is this people [...] Therefore there is falling upon it: army and hunger, fire and bloodshed,

21 theft and murder, slander and hatred, and the plundering of pillagers does very great damage. Therefore $[\ldots]$

22 is, as it may seem, many injustices and [there are] many unsteady pledges everywhere among everyone. [...]

23 and therefore in the country is falsehood at hand and wickedness [...]. [Many are]

24 commited to perjury and are bearing false witness and pledges are broken, often and frequently [...]

25 consider themselves aware and wise before God and the world. But weak is the [...]

26 wariest and wisest. Alas, much unlawfulness afflicts this people.

\section{Article III: Wulfstan's Pastoral Questions for Elfric, fol. 57v/30-42}

$33[\ldots]$ of the cattle that is dead because of castration, if we [...].

$35[\ldots]$ if one is allowed to $[\ldots]$

36 May one celebrate Mass and not receive the Eucharist? May one baptise with bishop's chrism

37 on Thursday before Easter? And why must one not use the old year's chrism?

38 On how one may marry relatives and what be prima progenies, what secunda?

39 Whether we are permitted to fight out of necessity against those who destroy flocks and settlements?

40 Whether we may order thieves to be slain, now that we cannot restrain them otherwise?

41 Whether one may consume blood if it is made into food and also [into drink]?

42 May one scrape wine-bread into the chalice, if there were any more wine left?

Article IV: A Version of Napier Homily XXV (HomU 24 [Nap 25]; ECHOE Homily 130.d), fol. $58 \mathrm{r} / 6-58 \mathrm{v} / 3$

6 Dearly beloved, understand eagerly how

7 great the need is for Christians that they have accurate knowledge of their baptism

8 and that they know the right faith and keep it with constancy. Therefore

9 one must not baptise any heathen, if he has the age and understanding

10 to be able to learn what baptism means and what the faith is, not at all

11 before he learns, that he may know what it signifies. However, afterwards

12 he will be worthy of baptism, after he understands it well with a

13 righteous belief. Those who were baptised in their youth, then, have great need

14 that they keenly learn after they have the age

15 and understanding that enable them to learn. [And that they may under-

16 stand] the right faith and that they have accurate knowledge of their baptism.

17 The [man who] does not have the right faith [he will not achieve anything 
18 unless] he learns so that he may know it and afterwards gladly

19 keep it. We may hardly baptise the man who does not understand the meaning of his Christendom,

20 nor wishes to learn so that he may have accurate knowledge. It may therefore

21 be better for him that he had never become a human being

22 when he was created, he who does not want to take possession of his Christendom. Dearly beloved,

23 that he may have accurate understanding, however, that is the need of a Christian:, that he may meditate

24 and ask eagerly about how this world first came into being. [And]

25 further that he may know how Christ came to humankind

26 and how he suffered death for us, and how he rose from death

27 and how he ascended into the heavens and how he will afterwards come thence

28 to the Great Judgement to which we all must come. At that

29 Judgement he will reveal to us his bleeding side and his pierced

30 hands and the crown of thorns and the same cross

31 on which he was hung for our necessity. And then he will

32 be resolute to know about us and how we have kept our Christendom.

33 Well then betide the one who has kept it well.

34 And woe to him then, who would not take care of it before as he should have.

35 But let us therefore act as is most necessary for us, let us help ourselves as long as

36 we can and have the chance to. Let us always have the right faith and [...]

37 the less we will be lost, when we least expect it.

38 Let us love God before all other things [and do his will as

\section{/58v/}

1 we most diligently can, then he will reward us for it, as is dearest

2 to us, whenever we need it the most. Praise and glory be ever to him,

3 all world without end. Amen.] 


\section{An die Setzerei:}

\section{Die Abbildungen (Plates 2-5) bitte am Ende des Aufsatzes platzieren}

Plate 2: London, British Library, Additional 38651, fol. 57r (multispectral image). (C) The British Library Board 2018.

Plate 3: London, British Library, Additional 38651, fol. 57v (multispectral image). (C) The British Library Board 2018.

Plate 4: London, British Library, Additional 38651, fol. 58r (multispectral image). (C) The British Library Board 2018.

Plate 5: London, British Library, Additional 38651, fol. 58v (multispectral image). (C) The British Library Board 2018.

\section{Works Cited}

Barrow, Julia. 2004. "Wulfstan and Worcester: Bishop and Clergy in the Early Eleventh Century". In:

Townend 2004, 141-159.

Becher, Richard. 1910. Wulfstans Homilien. Leipzig: Sturm \& Koppe.

Bethurum, Dorothy. 1942. “Archbishop Wulfstans's Commonplace Book”. PMLA 57: 916-929.

Bethurum, Dorothy (ed.). 1957. The Homilies of Wulfstan. Oxford: Clarendon.

Bethurum, Dorothy. 1966. "Wulfstan”. In: Eric Gerald Stanley (ed.). Continuations and Beginnings: Studies in Old English Literature. London: Nelson. 210-246.

Bock, Oliver. 2015. "C. Maier's Use of a Reagent in the Vercelli Book". The Library 16: 249-281.

Bosworth-Toller $=$ Bosworth, Joseph and Thomas N. Toller (eds.). 1898. An Anglo-Saxon Dictionary. Oxford: Oxford University Press; Thomas N. Toller (ed.). 1921. An Anglo-Saxon Dictionary: Supplement. Oxford: Oxford University Press; Campbell, Alistair. 1972. Enlarged Addenda and Corrigenda to the Supplement. Oxford: Oxford University Press.

Browe, Peter. 2003. Die Eucharistie im Mittelalter. Liturgische Forschungen in kulturwissenschaftlicher Absicht. Hubertus Lutterbach and Thomas Flammer (eds.). Vergessene Theologen I. Münster: LIT Verlag.

Brunner, Karl. 1965. Altenglische Grammatik. 3rd ed. Tübingen: Niemeyer. Campbell, Alistair. 1959. Old English Grammar. Oxford: Clarendon. 
Catalogue of the Additions to the Manuscripts in the British Museum (in the years

MDCCCCX-MDCCCCXV), vol. 19 (London: William Clowes \& Sons, 1925).

Chapman, Don. 2017. "Fixity and Flexibility in Wulfstan's Binomials". In: Joanna Kopaczyk and

Hans Sauer (eds.). Binomials in the History of English: Fixed and Flexible. Cambridge:

Cambridge University Press. 41-62.

Clayton, Mary. 2002. “An Edition of Ælfric's Letter to Brother Edward”. In: Elaine Treharne and Susan Rosser (eds.). Early Medieval English Texts and Interpretations: Studies Presented to Donald G. Scragg. Tempe, AZ: Arizona Center for Medieval and Renaissance Studies. 263283.

Clemoes, Peter. 1959. “The Chronology of Ælfric's Works”. In: Peter A. M. Clemoes (ed.). The Anglo-Saxons: Studies in Some Aspects of Their History and Culture Presented to Bruce Dickins. London: Bowes \& Bowes. 212-247.

Cockayne, Thomas Oswald (ed.). 1864-1866. Leechdoms, Wortcunning and Starcraft of Early England: Being a Collection of Documents for the most Part Never Before Seen. 3 vols. London: Longman, Green, Longman, Roberts, and Green. Reprint 1965. Wiesbaden: Kraus.

Cross, James E. and Jennifer Morrish Tunberg (eds.). 1993. The Copenhagen Wulfstan Collection, Copenhagen Kongelige Bibliotek Gl. Kgl. Sam. 1595. EEMF 25. Copenhagen: Rosenkilde \& Bagger.

Cross, James E. and J. E. Brown. 1992. "Wulfstan and Abbo of Saint-Germain des-Pres". Medievalia 15: 71-91.

Cross, James E. 1993. "Atto of Vercelli, De pressuris ecclesiasticis, Archbishop Wulfstan, and Wulfstan's 'Commonplace Book'”. Traditio 48: 237-246.

Cross, James E. and Andrew Hamer (eds.). 1999. Wulfstan's Canon Law Collection. Cambridge: Brewer.

Dance, Richard. 2004. “Sound, Fury and Signifiers; Or Wulfstan's Language”. In: Townend 2004, 29 61.

Daniels, Antonius J. 1904. "Kasussyntax zu den (echten und unechten) Predigten Wulfstans”. Unpubl. $\mathrm{PhD}$ dissertation, Universiteit Leiden.

Dodd, Loring H. 1908. A Glossary to Wulfstan's Homilies. New York, NY: Holt.

DOE = Dictionary of Old English in Electronic Form, A-H. 2016. Ed. Antonette diPaolo Healey et al. Toronto: University of Toronto. $<\mathrm{http}: / /$ www.doe.utoronto.ca $>$.

DOEC = Dictionary of Old English Web Corpus. 2007. Ed. Antonette diPaolo Healey et al. Toronto: University of Toronto. $<$ http://www.doe.utoronto.ca/pages/pub/web- corpus.html>.

Dunkhase, Heinrich. 1906. Die Sprache der Wulfstanschen Homilien in Wulfgeats Handschriften. Jena: Universitätsbuchdruckerei.

Elliot, Michael. D. and Tristan G. Major (eds.). 2013. AElfric: The Letters. $<$ http://groups.chass.utoronto.ca/aelfric/AEL1.html> [last accessed 07 April 2018]. 
Fehr, Bernhard. 1914. (ed.). Die Hirtenbriefe Elfrics. Hamburg: Grand. Reprint with additions by Peter Clemoes 1966. Darmstadt: Wissenschaftliche Buchgesellschaft.

Fortescue, Adrian. 1950. The Mass: A Study in the Roman Liturgy. London: Longmans, Green \& Co. Fowler, Roger (ed.). 1972. Wulfstan's Canons of Edgar. EETS OS 266. London: Oxford University Press.

Fuchs, Robert. 2003. "The History of Chemical Reinforcement of Texts in Manuscripts: What Should we Do Now?". Care and Conservation of Manuscripts 7: 159-170.

Gameson, Richard. 1996. "Book Production and Decoration at Worcester in the Tenth and Eleventh Centuries". In: Nicholas Brooks and Catherine Cubitt (eds.). St Oswald of Worcester: Life and Influence. London: Leicester University Press. 194-243.

Gatch, Milton McCormick. 1977. Preaching and Theology in Anglo-Saxon England: Alfric and Wulfstan. TorontoUniversity of Toronto Press.

Gneuss, Helmut. 2009. Alfric of Eynsham: His Life, Times, and Writings. Old English Newsletter Subsidia 34. Kalamazoo: Medieval Institute Publications.

Gneuss, Helmut and Michael Lapidge. 2014. Anglo-Saxon Manuscripts: A Bibliographical Handlist of Manuscripts and Manuscript Fragments Written or Owned in England up to 1100. Toronto: University of Toronto Press.

Godden, Malcolm R. 2004. "The Relations of Wulfstan and Ælfric: A Reassessment”. In: Townend 2004, 353-374.

Green, R. P. H. (ed. and trans.). 1995. Augustine: De Doctrina Christiana. Oxford: Clarendon.

Hall, Thomas N. 2004. "Wulfstan's Latin Sermons”. In: Townend 2004, 93-139.

Hill, Joyce. 1985. “Aelfric's 'Silent Days””. Leeds Studies in English 16: 118-131.

Hill, Joyce. 2004. “Archbishop Wulfstan: Reformer?”. In: Townend 2004, 309-324.

Hill, Joyce. 2009. “Ælfric: His Life and Works.” In: Hugh Magennis and Mary Swan (eds.). A Companion to Alfric. Leiden: Brill. 35-65.

Hohler, Christopher, 1975. "Some Service Books of the Later Saxon Church". In: David Parsons (ed.). Tenth-Century Studies: Essays in Commemoration of the Millennium of the Council of Winchester and Regularis Concordia. London: Phillimore. 60-83, 217-227.

Jones, Christopher A. 1998. “Two Composite Texts from Archbishop Wulfstan's 'Commonplace Book': The De ecclesiastica consuetudine and the Institutio beati Amalarii de ecclesiasticis officiis". Anglo-Saxon England 27: 233-271.

Jones, Christopher A. 2004. "Wulfstan’s Liturgical Interests". In: Townend 2004, 325-352.

Jones, Christopher A. 2005. "The Chrism Mass in Later Anglo-Saxon England". In: Helen Gittos and M. Bradford Beddingfield (eds.). The Liturgy of the Late Anglo-Saxon Church. Henry Bradshaw Society, Subsidia V. London: Boydell. 105-142.

Jost, Karl. 1932. "Einige Wulfstantexte und ihre Quellen”. Anglia 56: 265-315.

Jost, Karl. 1950. Wulfstanstudien. Bern: Francke. 
Jost, Karl. 1959 (ed.). Die "Institutes of Polity, Civil and Ecclesiastical”: Ein Werk des Erzbischof Wulfstans von York. Bern: Francke.

Ker, Neil R. 1948. "Hemming's Cartulary: A Description of Two Worcester Cartularies in Cotton Tiberius A.xiii”. In: R. W. Hunt, W. A. Pantin and R. W. Southern (eds.). Studies in Medieval History: Presented to Frederick Maurice Powicke. 49-75.

Ker, Neil R. 1949. “Old English Notes Signed 'Coleman””. Medium AEvum 18: 29-31.

Ker, Neil R. 1957. A Catalogue of Manuscripts Containing Anglo-Saxon. Oxford: Clarendon.

Ker, Neil R. 1971. "The Handwriting of Archbishop Wulfstan”. In: Peter Clemoes and Kathleen Hughes (eds.). England before the Conquest: Studies in Primary Sources Presented to Dorothy Whitelock. Cambridge: Cambridge University Press. 315-331.

Kinard, James Pinckney. 1897. A Study of Wulfstan's Homilies: Their Style and Sources. Baltimore: John Murphy \& Co..

Klauser, Theodor. 1979. A Short History of the Western Liturgy. Oxford: Oxford University Press.

Kubouchi, Tadao. 1999. From Wulfstan to Richard Rolle: Papers Exploring the Continuity of English Prose. Cambridge: Brewer.

Lenker, Ursula. 1999. "The West-Saxon Gospels and the Gospel-Lectionary in Anglo-Saxon England: Manuscript Evidence and Liturgical Practice”. Anglo-Saxon England 28: 141-178.

Liebermann, Felix (ed.). 1903-1916. Die Gesetze der Angelsachsen. 3 vols. Halle a.d.S.: Niemeyer.

Loyn, Henry R. (ed.). 1971. A Wulfstan Manuscript, Containing Institutes, Laws and Homilies. British Museum, Cotton Nero A.i. EEMF 17. Copenhagen: Rosenkilde \& Bagger.

Mann, Gareth. 2004. “The Development of Wulfstan's Alcuin Manuscript”. In: Townend 2004, 235278.

Masters Hollowell, Ida. 1982. “On the Two-Stress Theory of Wulfstan's Rhythm", Philological Quaterly 61: 1-11.

McIntosh, Angus. 1948. "Wulfstan's Prose". Proceedings of the British Academy 34: 109-142.

Menner, Robert J. 1948. “Anglian and Saxon Elements in Wulfstan's Vocabulary”. Modern Language Notes 63: 1-9.

Mitchell, Bruce. 1985. Old English Syntax. 2 vols. Oxford: Clarendon.

Mohrbutter, Alois. 1885. Darstellung der Syntax in den vier echten Predigten des ags. Erzbischofs Wulfstan. Lübeck: Rahtgens.

Morris, Richard (ed.). 1868. Old English Homilies and Homiletic Treatises (Sawles Warde, and Đe Wohunge of Ure Lauerd: Ureisuns of Ure Louerd and of Ure Lefdi, \&c.) of the Twelfth and Thirteenth Centuries. EETS os 29. London: Trübner.

Napier, Arthur. 1882. Über die Werke des altenglischen Erzbischofs Wulfstan. Weimar: HofBuchdruckerei.

Napier, Arthur (ed). 1883. Wulfstan: Sammlung der ihm zugeschriebenen Homilien nebst Untersuchungen über ihre Echtheit. Berlin: Weidmann. Reprint with bibliographical appendix by Klaus Ostheeren 1967. Dublin and Basel: Niehans. 
NRSV = The New Oxford Annotated Bible. New Revised Standard Version with the Apocrypha. 2010.

Ed. Michael D. Coogan et al. 4th ed. Oxford: Oxford University Press.

Ogawa, Hiroshi. 2010. Language and Style in Old English Composite Homilies Tempe, AZ: Arizona Center for Medieval and Renaissance Studies.

Orchard, Andy. 1992. "Crying Wolf. Oral Style and the Sermones Lupi”. Anglo-Saxon England 21: 239-264.

Orchard, Andy. 2002. “On Editing Wulfstan”. In: Elaine Treharne and Susan Rosser (eds.). Early English Texts and Interpretations. Studies Presented to Donald G. Scragg. Tempe, AZ: Arizona Center for Medieval and Renaissance Studies. 311-340.

Orchard, Andy. 2004. "Re-editing Wulfstan. Where's the Point?”. In: Townend 2004, 63-91. Orchard, Andy. 2007. "Wulfstan as Reader, Writer, and Rewriter". In: Aaron J. Kleist (ed.). The Old English Homily: Precedent, Practice, and Appropriation. Turnhout: Brepols. 311-341.

Orchard, Andy. 2012. "The Library of Wulfstan of York”. In: Richard Gameson (ed.). The Cambridge History of the Book in Britain. Cambridge: Cambridge University Press. 694-700.

$P L=$ Patrologia Latina. 1844-1864. Ed. J.-P. Migne. 221 vols. Paris.

Pons-Sanz, Sara María. 2007. Norse-Derived Vocabulary in Late Old English Texts: Wulfstan's Works, a Case Study. Odense: University Press of Southern Denmark.

$R G G=$ Die Religion in Geschichte und Gegenwart. 1957-1965. Ed. Kurt Galling et al. 3rd ed., 7 vols. Tübingen: Mohr.

Rudolf, Winfried. 2012. "The Addition and Use of Running Titles in Manuscripts Containing Old English”. In: Elaine Treharne, Orietta Da Rold, and Mary Swan (eds.). Producing and Using English Manuscripts in the Post-Conquest Period. New Medieval Literatures 13. Turnhout: Brepols. 49-97.

Rudolf, Winfried. 2015. "Quoting and Translating Latin in the Old English Homilies of the Vercelli Book". In: Jenny Arendholz, Wolfram Bublitz and Monika Kirner (eds.) The Pragmatics of Quoting Now and Then. Berlin \& Boston: De Gruyter. 271-290.

Scragg, Donald G. 1977. "Napier’s 'Wulfstan' Homily XXX: Its Sources, Its Relationship to the Vercelli Book and Its Style." Anglo-Saxon England 6: 197-211.

Scragg, Donald G. (ed.). 1992. The Vercelli Homilies and Related Texts. EETS OS 300. Oxford: Oxford University Press.

Scragg, Donald G. 1999. Dating and Style in Old English Composite Homilies. Cambridge: Department of Anglo-Saxon, Norse and Celtic, University of Cambridge.

Skeat, Walter W. (ed.). 1881-1900. Ælfric's Lives of Saints. 4 vols. EETS OS 76, 82, 94, 114. London: Trübner. Reprint in 2 vols. 1966.

Matthew Townend (ed.). 2004. Wulfstan, Archbishop of York: The Proceedings of the Second Alcuin Conference. Turnhout: Brepols. 
Stokes, Peter A. 2011. "Recovering Anglo-Saxon Erasures: Some Questions, Tools and Techniques". In: Leo Carruthers, Raeleen Chai-Elsholz and Tatjana Silec (eds.). Palimpsests and the Literary Imagination of Medieval England. New York: Palgrave Macmillan. 35-60.

Tristram, Hildegard. 1995. Early Insular Preaching: Verbal Artistry and Method of Composition. Österreichische Akademie der Wissenschaften. Philosophisch-Historische Klasse Sitzungsberichte 623. Veröffentlichungen der keltischen Kommission 11. Wien: Verlag der österreichischen Akademie der Wissenschaften.

Wanley, Humfrey. 1705. Antiquae Literaturce Septentrionalis Liber Alter, seu Humphredi Wanleii Librorum Vett. Septentrionalium, qui in Anglice Bibliothecis extant [...] Catalogus HistoricoCriticus. Oxford.

Whitelock, Dorothy. 1942. “Archbishop Wulfstan, Homilist and Statesman”. Transactions of the Royal Historical Society Ser. 4.24: 25-45.

Whitelock, Dorothy. 1948. "Wulfstan and the Laws of Cnut". The English Historical Review 63: 433452.

Whitelock, Dorothy (ed.). 1976. Sermo Lupi ad Anglos. 3rd ed. Reprinted with additional bibliography 1989. Exeter: Exeter University Press.

Whitelock, Dorothy. 1981. History, Law, and Literature in 10th-11th Century England. London: Variorum. XI: 42-60.

Wilcox, Jonathan. 1991. “Napier's 'Wulfstan'-Homilies XL and XLII: Two Anonymous Works from Winchester?". Journal of English and Germanic Philology 90: 1-19.

Wilcox, Jonathan. 1992. “The Dissemination of Wulfstan's Homilies: The Wulfstan Tradition in Eleventh-Century Vernacular Preaching". In: Carola Hicks (ed.). England in the Eleventh Century: Proceedings of the 1990 Harlaxton Symposium. Stamford: Watkins. 199-217.

Wilcox, Jonathan. 2000. "The Wolf on Shepherds: Wulfstan, Bishops, and the Context of the Sermo Lupi ad Anglos". In: Paul E. Szarmach (ed.). Old English Prose: Basic Readings. New York, NY: Garland. 395-418.

Winterbottom, Michael and Rodney. M. Thomson (eds. and trans.). 2002. William of Malmesbury: Saint's Lives. Lives of SS Wulfstan, Dunstan, Patrick, Benignus and Indract. Oxford: Clarendon.

Wormald, Patrick. 1999. The Making of English Law: King Alfred to the Twelfth Century. Volume 1: Legislation and its Limits. Oxford: Blackwell.

Wormald, Patrick. 2000. "Archbishop Wulfstan and the Holiness of Society". In: David A. E. Pelteret (ed.). Anglo-Saxon History: Basic Readings. New York: Garland. 191-224.

Wormald, Patrick. 2004. “Archbishop Wulfstan: Eleventh Century State-Builder”. In: Townend 2004, 9-28. 
Wright, Charles D. 2007. "Old English Homilies and Latin Sources.” In: Aaron J. Kleist (ed.). The Old English Homily: Precedent, Practice and Appropriation. Studies in the Early Middle Ages 17. Turnhout: Brepols. 15-66.

Zimmermann, Otto. 1888. Die beiden Fassungen des dem Abte AElfric zugeschriebenen Traktats über die siebenfältige Gabe des Heilgen Geistes. Leipzig: Hesse \& Becker. 
